\title{
Revealing colonial power relations in early childhood policy making: An autoethnographic story on selective evidence
}

\author{
Norma Rudolph
}

\begin{abstract}
The COVID-19 pandemic exposes uncertainty, instability and glaring inequality that requires urgent global policy decisions. Historically, bureaucrats regard uncertainty as the enemy and look for tested solutions (Stevens, 2011). In contrast, Fielding \& Moss (2010) acknowledge an uncertain future and encourage shifting policy making towards the search for possibilities instead of replicating singular solutions. Escobar (2020) advocates for pluriversal politics, with many possibilities created through collective decision-making by autonomous interlinked networks. In this paper, I combine autoethnography with policy analysis drawing on my own experience in South African early childhood policy making. I argue for a fresh decolonial debate about early childhood policy to replace dominant imported evidence-based narratives. I pay attention to power relations and examine, not only the content of evidence, but who has authority to speak (Mignolo, 2007). I introduce the bottom-up appreciative participatory dialogical policy making in the Gauteng Impilo project (1996 - 2000), as one attempt to resist the dominant policy trajectory. Local networks, that can inform policy making and resource allocation though conversation and action, emerged from this experience. This article invites urgent inclusive policy debate that expands choices and can produce cumulative worthwhile change and new learnings to birth a better society.
\end{abstract}

\section{Article History}

Received: 18 August 2020

Accepted: 13 November 2020

\section{Keywords}

COVID-19; Autoethnography; Early childhood policy analysis; Decoloniality; South Africa

\section{Introduction}

Global instability and uncertainty during the COVID-19 pandemic brightly illuminate inequality and ecological precarity, calling for new ways of being and action for energy, food and education sovereignty ${ }^{2}$. Inequality has persisted in South Africa long after the end of Apartheid. Before coming to power in 1994, the African National Congress (ANC) promised to redress the legacy of Apartheid. While much has been achieved, there have been major failures and South Africa is one of the most unequal countries in the world. Before the pandemic, nearly one-third of South Africa's children did not eat sufficient nutritious food and twenty percent of the population was food insecure ${ }^{3}$. The combination of poor water policy, degradation of infrastructure, and insufficient action to address climate change, has left a large portion of the population having to walk long distances and queue for limited access to water. The majority of South Africans do not have access to good quality health, education and other essential social services.

On 15 March 2020, a national state of disaster was declared in South Africa (Gazette No 43096) and from 26 March everyone was confined to their homes. The first five weeks of the South African lockdown went further than most countries, as adults and children were not permitted to leave their homes for exercise or sunlight, or even to take their dogs for a walk. However, government did not plan to simultaneously implement complementary testing, tracing and measures to mitigate the effects of the

\footnotetext{
${ }^{1}$ University of Jyväskylä, Faculty of Education and Psychology, Education, Jyväskylä, Finland, normarudolph610@gmail.com; norma.1.rudolph@student.jyu.fi, ORCID https://orcid.org/0000-0002-2431-0236

2 While, I argue that COVID-19 highlights the need for dialogue, my policy analysis does not relate directly to COVID-19.

${ }^{3}$ More than half a million households with children aged five years or younger experienced hunger in 2017. http://www.statssa.gov.za/?p=12135
} 
Revealing colonial power relations in early childhood policy...

lockdown on the poor ${ }^{4}$. A small percentage of the population live in homes with gardens, but most live in densely populated informal settlements or inner-city high-rise buildings. Physical distancing is impossible for the majority. In some 'homes', ten or more adults and children (who might not all be blood relatives) could be living together in a single small room. While a few children travel to school in private cars, the majority walk long distances or use public transport. The most accessible form of public transport is minibus taxis. The protest by taxi owners against the government policy that taxis must reduce the number of passengers on each trip during the pandemic, led to the revised decision that they merely needed to keep one window open. Children in a few homes have devices and internet access and have been able to continue schooling and interact with friends on-line. Most children experienced precarity and uncertainty and the majority of school children were not receiving the one free meal at school per day that they rely on. The National Income Dynamic Study - Coronavirus Rapid Mobile Survey (NIDS-CRAM) 5 survey in the second month of the lockdown found that $7 \%$ of adults and $4 \%$ of children were perpetually hungry (hunger "every day" or almost every day) and half of the respondents had run out of money to buy food that month.

Soon after the start of the lockdown President Ramaphosa confirmed that the pandemic had exacerbated inequality, that government food distribution had been unable to meet the "huge need" and he promised to "forge a new economy".... "founded on fairness, empowerment, justice and equality" . Eighteen weeks after the disaster had been declared and the level of lockdown had been lowered from level 5 to 3 , the rate of infection and death had started to increase rapidly, and more than 5000 people had died. The focus on COVID-19 had compromised human immunodeficiency virus (HIV) and tuberculosis (TB) testing and treatment as well as infant immunization and ante-natal services. Debate raged about opening schools and early childhood services and several court cases were won against government, including a court order that Grade $\mathrm{R}^{7}$ and preschool children who attend non-government institutions can return to their centres and that the Department of Basic Education (DBE) provide one nutritious meal a day to all qualifying school children whether they had returned to class or not. While insufficient, unfunded and underfunded early childhood services collapsed, the Minister of Social Development announced the planned employment of thirty-six thousand (36 000) youth as compliance monitors in Early Childhood Development (ECD) centres and partial care facilities at a cost of 1.3 billion Rands ${ }^{8}$.

In this article, I examine ANC policy-making for young children since the first democratic election in 1994 and invite debate about how policy-making might need to change to achieve Ramaphosa's recommitment to the pre 1994 ANC goals of building a convivial society. I analyse power relations, dominant discourses and subjugated attempts to tell a different story. As COVID-19 spotlights uncertainty and glaring inequality, this autoethnographic story invites conversation about early childhood policymaking in South Africa. As an example of the primary focus of ANC early childhood policy and financing, I trace the introduction and expansion of the extension of primary school downward, through what is referred to in South Africa as Grade R. South Africa is poised to introduce Grade RR, thus adding an additional compulsory year before Grade $\mathrm{R}$ and entry into the formal primary school system, despite acknowledging that in the past 20 years Grade $\mathrm{R}$ has increased inequality rather than decreased it. I argue for urgent inclusive debate about early childhood policy.

\section{Walking and Talking the World into Being for a Decolonial Methodology}

This is not an easy story to tell. I aim firstly to deploy an approach, 'reflexivity of discomfort' (Pillow, 2003), to reveal post-Apartheid discourses and power relations that informed the initial decisions to pilot

\footnotetext{
42020 Coronavirus Rapid Mobile Survey compiled by 30 social scientists from five different universities across the country https://cramsurvey.org/reports/.

52020 Coronavirus Rapid Mobile Survey compiled by 30 social scientists from five different universities across the country https://cramsurvey.org/reports/.

${ }^{6}$ https://apnews.com/3982bc2db40764467e8164f03c362aa9

${ }^{7}$ Initially referred to as the "Reception Year', Grade R is a year-long programme for children in the year they turn 5 and just before they enter the first year of primary schooling. These Grade R classes can be in schools or in the community

${ }^{8}$ https://www.gov.za/speeches/minister-lindiwe-zulu-socioeconomic-interventions-mitigate-impact-coronavirus-covid-19
} 
and then formally introduce Grade R in 2001. Secondly, I wish to stimulate debate about current early childhood policy in South Africa by "pushing the reader to analyse, question, and re-question her/his own knowledge and assumptions brought to the reading" the same way I approach writing in this article (Pillow, 2003, p. 188). In order to stimulate the debate about policy-making for young children in South Africa, I use an autoethnographic method drawing on my own experiences in policy-making in the same geography and period of the policy-making discussed in this article. I draw on my memories as data to guide my story about juggling complex relationships with a variety of different institutions and individuals with different beliefs, paradigms and priorities. I contextualize this analysis within the framework of relevant theorists, and with reference to my archive which, in addition to published literature includes a variety of original documents, such as original reports and memoranda, personal communications and journal entries. I chose autoethnography for the possibility of disrupting colonial research methods, by reclaiming the subjective voice of those in marginalised communities, with whom I engaged in participatory action research over three decades in different geographic contexts. Autoethnography has been positioned historically as disrupting Eurocentric norms of research practice and representation (Chawla \& Atay, 2018). I combine autoethnography and analysis of policy and policy-making processes. Through focusing on questions about included and excluded actors, selected stories and the ends that are served by such choices (Chawla \& Atay, 2018), I challenge myself, as the researcher, to pay attention to emotions and affect in all aspects of policy-making and research.

I draw on Pillow's (2003) construction of 'reflexivity of discomfort' to help me think differently and try to avoid falling into my own trap of using the same language or categories that I reject. I try to be accountable to the "struggles for self-representation and self-determinism" of the characters in my story, including myself (Pillow, 2003, p. 193). I continuously interrogate my shifting power relations and try to write the account in a way that could provide multiple possibilities. I avoid confessing personal historical failures or applauding my successes. Whether or not the reader challenges the 'truthfulness' of my (re)telling, my aim remains constant: to stimulate discussion about future policy decisions. In this methodology, ethics is not derived from official 'ethical clearance' of the research design or informed consent of participants. The methodology "resituates ethics as the responsibility of researchers and readers" (Pillow, 2003, p. 191 referring to St. Pierre). As author, I pay attention to the ethical implications of all my research decisions and invite all to theorize our own lives and examine different frames.

I construct a theoretical framework that combines Stevens' (2011) analysis of the social world of policy-making with the literature reconceptualizing early childhood education as well as decoloniality. Moss and others discuss the transformation in early childhood policy-making (Moss \& Dahlberg, 2008; Fielding \& Moss, 2010; Moss, 2007, 2014, 2019). They suggest that by being open to possibilities and nurturing a willingness for transformation, it is possible to move towards one of many versions that can produce cumulative worthwhile change and new learning (Fielding \& Moss, 2010, p. 135). Escobar (2020) advocates for pluriversal politics, with many possibilities created through collective decision-making by autonomous interlinked networks. Stevens explains that there is very little examination of policy-making process and draws on his own observation and participation in the United Kingdom to argue that 'evidence' is used as a tool of persuasion to sell certain policy proposals that have the greatest chance of being accepted within the particular context in which they are being presented (Stevens, 2011). He argues that support for policy proposals relies on strategies such as avoiding complexity and uncertainty, as well as the 'trustworthiness' of the proponents. He describes how 'evidence' can be used to shift attention away from inequality and the challenging of "contemporary distribution of power" (Stevens, 2011, p. 18).

I acknowledge Pam Christie's argument that "the nature of government in a modern state entails engaging with particular practices and ways of thinking which themselves set limits to the changes that are conceivable and credible" (Christie, 2006, p. 374). I analyse these practices and ways of thinking in order to expose the danger of dominant policy-making practices and uncover the "disorder, confusion and chance happenings" that might have contributed to decisions that appear, in retrospect, to have been made with careful consideration in the best interests of all children (Christie, 2006, p. 375 referring to Foucault (1997)). I wish to explore the 'rationalities that normalize acts of power' (Christie, 2006; Foucault, 2000; 
Revealing colonial power relations in early childhood policy...

Green, 2012), and invite debate and discussion about other possibilities and opportunities for resistance. I hope to stimulate conversation across the country, in government, civil society, homes and other gathering places, about well-being and food, land, energy and education sovereignty.

\section{Fragmented and Inequitable Services for Young Children in South Africa}

When I entered the early childhood field during the last decade of Apartheid, the available government funded services were unevenly distributed in terms of race and place, with urban children classified as 'white' receiving most resources, and rural children classified as 'black' receiving little if anything. Responsibilities were fragmented across different government departments, including education and welfare. The segregated education system provided well-resourced pre-primary schools for children from 3 to 6 years old, mainly in urban garden suburbs, where only families classified as 'white' were permitted to live. Before 1994, the most common form of provision was community-based 'educare centres' for children between the ages of 3 to 6 years. These 'informal' services were the responsibility of the Department of Welfare, which provided a small subsidy for a small number of educare services in mostly black urban areas; the rest were privately funded. Staff had little or no training and relied on whatever minimal fees that very poor families could afford. In the 1994 Situation Analysis, Mary Newman described educare services, explaining that, "There are many places where children are crowded together, often with little or no food supplies, little adult attention and certainly no educational stimulation" (September \& Mokgoro, 1993, p. 19).

Different kinds of organisations offered adult early childhood training courses. Formal institutions, such as teacher training colleges, prepared preschool teachers in the education system and a few urbanbased non-governmental organisations offered short courses for 'practitioners' in 'informal' services. Between the mid-1980s and 1990s, the South African non-government ECD sector thrived and grew to about 100 training organisations (Van den Berg \& Vergnani, 1986). A number of foreign donors, including foreign government agencies that refused to cooperate with South Africa's apartheid government, redirected funding to non-government early childhood initiatives. Van den Berg and Vergnani offer a comprehensive account of the early childhood sector in South Africa in the mid-80s, identifying "an endemic and chronic disease of competition and suspicion" within the field and a volatile political climate with a "tumultuous level of conflict in many parts of the country" (Van den Berg \& Vergnani, 1986, p. 8-9). This continued into the mid-90s. At the same time the absence of government attention or regulation offered fertile ground for experimentation in the non-formal early childhood field. Some training organizations, that I will refer to as Resource and Training Organizations (RTOs), had started to introduce innovative family-based programs, such as home-visitors and Community-based Integrated Management of Childhood Illnesses (cIMCI). In particular, there were a small group of RTOs who were drawing on the work of Paulo Freire and the training of Anne Hope and Sally Timmel (Hope \& Timmel 1984), to use a conscientizing approach to empower marginalised communities. I started a small RTO called Woz'obona in the mid-80s, acknowledging that this was political work as we were essentially organising communities around the needs of young children (Rudolph, 1993). The Woz'obona curriculum was developed with marginalised partner communities from different parts of South Africa and drew on beneficiary visions of childhood and society (Rudolph, 1993).

\section{Getting Ready to Govern}

After the ANC and other organisations were unbanned on 2 February 1990, preparing for democracy was no longer clandestine. In October 1991, the Process of Multi-Party Negotiations for the transfer of power was initiated with preparation for the All-Party Congress. From 1991, while the multi-party negotiations determined the big issues for a democratic South Africa, such as control of the security forces, the electoral process, state media and finances, the early childhood sector was also busy with its own negotiations on a much smaller scale. While the alliance represented by the ANC in the national negotiations had been galvanised through the United Democratic Movement (UDM), in the 1980s there was still fragmentation in the early childhood sector. There were several interlinked processes that 
contributed to formulating the proposed policies that the ANC would take to the electorate. In terms of my story in this article, I introduce the 1992 National Education Policy Initiative (NEPI) and the ANC consultative process, including the 1992 Ready to Govern Conference.

ANC policy guidelines for a democratic South Africa were adopted at the National Ready to Govern Conference held on 31 May 1992. The ANC stressed its commitment to broad discussion and consultation, pointing out that the guideline would need to be adapted through consultation with the "broadest spectrum of South African public opinion", in order to draw on the depth and breadth of experiences (ANC, 1992a). The 1992 ANC policy aimed to reflect the values and ideals of equality, sustainability and self-determination set out in the Freedom Charter (1955) (ANC, 1992a). It also acknowledged the magnitude of problems generated by Apartheid and the transformational challenges that would require difficult choices, given the diversity of citizens and the legacy of physical separation, spiritual alienation and inequality (ANC, 1992a). The document emphasized the commitment to "equal rights, non-racialism, non-sexism, democracy and mutual respect" and "a broad, inclusive approach, free of arrogance or complexes of superiority or inferiority" (ANC, 1992a, A.1). The intention was to develop a vision of our country "not distorted by the prejudices and sectarianism that has guided viewpoints on race and gender, in the past". I was particularly encouraged by the expressed intention to "rely on the wisdom, life experiences, talents and know-how of all South Africans, women and men" in "finding solutions to the problems created by Apartheid" (ANC, 1992a, A.1). The introduction to this important initial ANC policy discussion document, as I read it, promised the beneficiaries of services (especially those most marginalized by Apartheid) the authority to speak and design the kind of policies that would best suit their diverse circumstances. I looked forward to contributing from my experience in this kind of 'bottom-up' consultative process.

\section{Side-lining Bottom up Consultative Processes}

The 1992 National Education Policy Initiative (NEPI), which analysed different policy options for an equitable education system in a democratic South Africa, constituted one important ANC-initiated policy investigation towards preparing to govern. The results of this collective work was published in a series of 12 reports, including 'Early Childhood Educare' (Taylor, 1992). As part of the NEPI investigation, Linda Biersteker brought together policy suggestions from different research initiatives and examined them in the light of the NEPI and Early Childhood Educare (ECE) Commission criteria (Biersteker, 1992). This document served as a summary of the NEPI ECE Research Group. I was a member of that group.

Biersteker isolated three main trends in terms of ECE services, taking into account the traditionally separate education and welfare policies at that time. These were "education policy re pre-primary education", "welfare policy re day care provision" and she then synthesized these two into a third position, which she referred to as "development policy re early childhood educare provision" (Biersteker, 1992, p. 2). Biersteker explains that the education sector responded to high drop-out and failure rates in the schooling system from a 'deficit' construction, proposing an additional year of provisioning within the primary school and emphasising 'school readiness' (Biersteker, 1992). Their proposal 'undervalued' the pre-primary programme for children aged three to six years, provided in the privileged education system. This position was also influenced by the one-year Bridging Period Programme that had been introduced by the Apartheid government. The welfare policy suggestions were based on full day care for children of mothers working outside the home, to be subsidized by government only for the very poor. This perspective prioritized children's care rather than educational needs.

The third 'development' position integrated education and care, within a broad context of health, education, community development and housing. It viewed the role of government policy as enabling and empowering communities to develop adequate services for their needs, in particular the holistic development of young children. This position generated more space for beneficiary agency and a wider range of possible programmes. At that time, many civic, early childhood and literacy programmes used an approach promoted in 'Training for Transformation' (Hope \& Timmel, 1984). This approach, influenced 
Revealing colonial power relations in early childhood policy...

by the work of Illich (1973) and Freire (1970) acknowledged the power of dialogue to transform relationships, build community and drive social change. While Biersteker's report offered an important first step in setting out the different positions and narratives, it failed to sufficiently acknowledge and describe the innovative conscientizing programmes that were not represented in the suggestions of the more established education research institutions.

As I review Biersteker's document, what jumps out is the number of powerful education players who suggested "the downward extension of the primary school by adding a preschool year for five-year olds, either at existing primary schools or in community schools" (Donaldson, 1992; Human Sciences Research Council [HSRC], 1981; Mehl, 1991; Reilly and Hofmeyr, 1983) (referred to in Biersteker, 1992, p. 2). This proposal was based on reports written by researchers published during apartheid and who worked in institutions such as the HSRC that was established and thrived during Apartheid.

Next in my story, I point to the way that a few influential individuals were able to subjugate other proposals and elevate the proposal to extend primary school downward.

\section{Reorganising Power Lines}

In the period leading up to the 1994 first democratic election, several different associations and umbrella organisations represented different groupings of early childhood training providers and practitioners. The history of separate services for different racial groups during Apartheid was reflected in national organisations. Among these, the South African Association for Early Childhood Educare (SAAECE) was the oldest and had been established by white nursery-school teachers in 1939. In the early 1980s, SAAECE began to open its membership to other population groups, but "continued to organise primarily in the urban areas and in relatively advantaged communities" (Williams \& Samuels, 2001, p. 14). In 1990, the National Interim Working Committee on Educare (NIWC) emerged from a consultative conference, hosted by the National Education Co-ordinating Committee (NECC) which was operating as the ANC Education Desk, to consider a proposed University programme. The conference rejected the proposal as it did not take sufficient account of the context. At the end of the meeting, several people were nominated to take forward the process of building unity in the sector.

I was one of about ten people nominated to this national committee that decided to call itself the National Interim Working Committee on Educare (NIWC), and we started to hold regular meetings in fivestar hotels, which were the only available racially integrated accommodation at the time. Despite the sector being predominantly female, all three NIWC office bearers, the National Chairperson, Organiser and Treasurer, were all men. After several meetings, a decision was made to approach the previously 'white' SAAECE to negotiate a 'settlement'. So, while the political parties negotiated the future of the country, the Educare sector held our own 'negotiations'. Williams and Samuels (2001) report that "After a gruelling process of negotiation, SAAECE and NIWC finally amalgamated in 1994 to form the Congress of Early Childhood Development (SACECD)" (Williams \& Samuels, 2001, p. 10). While this might have appeared to be a democratic process, unequal power relations in the sector, including patriarchy, meant that some individuals were able to dominate. The majority of early childhood practitioners and all beneficiaries were excluded from any debate. The late Roy Padayachie ${ }^{9}$, who also led the World Bank Research Group (Padayachie et al., 1994), had been consolidating his influence in the ANC and the early childhood sector. He had played an influential role in the early childhood policy-making processes leading up to the first democratic election and was elected as the first National Chairperson of the South African Congress of Early Childhood Development (SACECD) in 1994.

Padayachie explained, in a presentation to a 1993 ANC consultative meeting, that he saw his role as preparing the "educare constituency so that it is ready for the present challenge of building the new democratic order" (Padayachie, 1993c). However, it is evident from a range of documents in my archive that Padayachie was presenting a set of ideas to be accepted without discussion or debate (Padayachie,

\footnotetext{
${ }^{9}$ Roy Padayachie died of a heart attack on May 4, 2012, in Ethiopia while serving as South Africa's Minister of Public Service and Administration.
} 
1993a, 1993b, 1993c ${ }^{10}$. These ideas included a vision for policy, resource mobilization and an appropriate national organisation that "speaks with a united and powerful voice" (Padayachie, 1993c, p. 1). Only a small group of people regarded as 'experts' were involved in the consultative process. My persistent inquiries, as a member of a local ANC branch, suggest that no discussion about early childhood policy was taking place in local ANC branches. Even the records of the ANC consultation at provincial and national level show that there was no open-ended discussion of possibilities for early childhood policy (ANC, 1992a, 1992b, 1994).

\title{
A Charismatic Storyteller and an Accident: The Birth of Grade R
}

At the time while I was participating in those early consultations, I did not recognize Padayachie's strategy of building a single narrative as clearly as I do in retrospect. Padayachie's narrative echoed the 'education' perspective of the 1992 NEPI educare research proposals. This was also the perspective being promoted by the World Bank which commissioned a study led by Padayachie to investigate the downward extension of primary school (Padayachie et al., 1994). The power of this single story supported by the familiar Apartheid era discursive tropes, and education experts from the same era, and told by a politically savvy and influential storyteller displaced discussion about the other NEPI proposals. In particular, the proposal that emerged from the non-formal educare sector that had quietly been working in and with marginalized communities, could not mobilize the same authority. The more complex and innovative story that emerged from the bottom up, came with the uncertainty of empowering communities to design the kind of services that would support their visions of the childhoods and the society they hoped to achieve in a democratic South Africa.

The scope of this article does not allow for a detailed account of power relations and the 'accidents of history' during that period. However, to further illustrate the way that this single story emerged as the dominant narrative from the early ANC education consultation, I briefly trace some nodal moments in the 'ready to govern' consultative process. Despite the heartening ANC promise of consultation, I was perplexed to see how this recurrent single educare story, by an influential storyteller, emerged without any meaningful opportunities for debate and discussion. My analysis of archival documents, and enquiries of ANC leadership at the time, including Mary Metcalfe, head of the Education Desk, suggest that a critical historical accident might be found in a story that Metcalfe told me in 2015. The story is about an early ANC consultative meeting that took place before the 1992 Getting Ready to Govern Conference. The key controversial issue of the conference was the number of years of free and compulsory education that the ANC could afford. Financial modelling by the ANC leadership had determined that ten years would be the maximum. However, the student movement and the affiliates of the NECC ${ }^{11}$ that had argued as part of the political struggles for free education up to end of Grade 12, expected more than ten years. It was critical that this issue be resolved to avoid taking contestation into the election. Metcalfe explained:

\begin{abstract}
At the end of the day when we were carefully managing the report back to the conference, the late Ivy MatsepeCasaburri joined us as we were summarising and finalising the resolutions. She was a passionate supporter of educare (although not part of the educare sector) and asked why educare had not been included. We had been thinking specifically of schooling and had assumed that educare would be included more broadly outside of the school system. It was now too late to discuss this suggestion fully and she insisted that educare must be included. So, we included Grade $\mathrm{R}$ as the first year of 10 years of free and compulsory education. So, we now have Grade R with grades 1 to 9 as our 10 years of schooling but without the exit exam. Then this became some kind of rule (Mary Metcalfe, 2015) ${ }^{12}$
\end{abstract}

It seems that part of this accident of history was the complexity of 'educare', which straddled more than one ANC policy grouping in the consultative process. In addition, Padayachie had already started elevating the dominant coloniality story in senior ANC circles. Consequently, the Ready to Govern Conference Report says little specifically about educare, but commits to

\footnotetext{
${ }^{10}$ Retrieved from my archive.

11 The National Education Crisis Committee (NECC) was launched in early 1986 with the support of the United Democratic Front (UDF) and Congress of South African Trade Unions (COSATU), in the context of militant anti-apartheid student action.

12 Personal communication in my archive.
} 
Revealing colonial power relations in early childhood policy...

... the provision of a minimum of ten years of free and compulsory education, which shall include, where possible, one year of preschool education. This commitment is based on our belief that ten years of quality education is the minimum necessary to prepare individuals to participate in the economy and society (ANC, 1992a, Section K.Education, subsection 1. Provision ).

This position based on colonial thinking that had emerged from the Apartheid education era was taken to the election as ANC policy and has persisted into the present.

\section{Ironed power lines: ANC policy for young children}

According to the three key documents produced by Padayachie between March and October 1993 (Padayachie, 1993a, 1993b, 1993c) ${ }^{13}$, he emphasized the need for a movement that "speaks with a united and powerful voice". He promoted NIWC, which he chaired at the time, as the appropriate organisation to lead this process of preparation and articulating the selected education policy position (Padayachie, 1993a, p. 1). He prioritized consensus and referred to several 'discussion' documents and 'consultative meetings' that did not provide any meaningful opportunities for debate or engagement. For example, an invitation $^{14}$ to an ANC Early Childhood Educare Policy Workshop, held on 2 September 1993 in Cape Town, lists the aims as: "To discuss and make recommendations for ANC Early Childhood Educare Policy; and To establish criteria and nominate a representative to the Regional Education and Training Forum 11 and 12 September" (Padayachie, 1993b, p. 1 from archive of Linda Biersteker). A wide range of complex policy issues from guiding principles to budgets, governance to redistribution were all to be discussed, alongside the nomination of one representative to the ANC regional forum, in the four hours scheduled for the meeting (Padayachie, 1993b, p. 1-2). The style of the invitation and the unachievable agenda reflect the intention to inform and vote for given decisions, rather than consult.

The 'consultative' documents circulated by Padayachie present a deficit model of the users of services and assume that communication will be in one direction, from services to parents who need 'to learn about and respond to their children's developmental needs' (Padayachie, 1993a, p. 2). There is no reference to parents and communities knowing what is best for their children and society, nor how the proposed services would best serve their needs. The discourse frames parents as merely users of services in order "to take up work or further education' (Padayachie, 1993a, p. 2). The recommendations focus on the establishment of structures and limits local influence, rather than encouraging opportunities for listening, experimentation and meaningful participation. The emphasis is on generating awareness of the need for 'early childhood care and development', based on an assumption that there is consensus about what that means. The new umbrella organisation that Padayachie was leading is positioned as the primary credible influence.

It seems Padayachie was a great bureaucrat, and excelled in performing what Stevens (2011) refers to as "bureaucratic reason", by combining "effective persuasion" with "control of uncertainty" and his personal "career incentives" (Stevens, 2011, p. 12). Padayachie selected the proposal with least uncertainty to tell a story about a new policy area, and at the same time identified himself as the primary storyteller. I believe Padayachie was using discursive tropes, not to bring like-minded people into an advocacy coalition, but rather to show his worth in this "thought world" (Stevens, 2011, p. 13). Padayachie reinforced, rather than challenged, the "fundamental assumptions and tropes" of the preferred policy narratives of education experts of that time (Stevens, 2011, p. 14). The story Padayachie chose was from the Apartheid era and so, perhaps unwittingly, he carried colonial thinking into the new democratic policy terrain.

\section{Creating Impilo as a Participatory Alternative}

My position was different to that of Padayachie. I was inspired by the ingenuity and survival strategies of the marginalized communities in which I had lived and worked. I had started to read about integrated early childhood approaches and I was particularly inspired by the work of Marta Arango in

\footnotetext{
13 Retrieved from my personal archive.

14 The document does not indicate the author, but it is most likely from Roy Padayachie.
} 
Colombia (Arango \& Nimnicht, 1987, 2004). She and her husband wrote about decolonizing education and human development strategies, and introduced me to an "integrated policy" for young children as part of the "hope for creating a new society with social and economic justice" based on what citizens desire (Arango \& Nimnicht, 1987, p. 37). It was with this understanding that I continued to challenge my own colonial thinking and to listen for other stories and possibilities for social justice. In particular, I took up this challenge through Impilo, which used an experimental integrated approach in a three-year appreciative participatory action research process in 1000 community-managed sites in Gauteng.

Impilo was based on the principles stated in the 1996 Interim Policy for Early Childhood (IPECD), which was the first step that the National Department of Education (DoE), as lead department, took towards realising the ANC's promise for young children, families and communities. I was one of three ECD specialists given the task of drafting the IPECD (DoE, 1996). Our draft document emphasised an integrated approach, based on the narratives of the progressive non-formal sector, with possibilities for local communities to produce a range of stories about the kinds of services that would best enable them to support the well-being of their young children. When the policy was published, the IPECD acknowledged the importance of an integrated approach to address the "basic needs of families for shelter, water and sanitation, primary health care, nutrition, employment and adult basic education", but it only committed funding for the Reception Year ${ }^{15}$ (DoE, 1996, p. 6). The interim policy envisioned that eventually children of Reception Year age would all be included in the school system. Consequently, it emphasized the need for this one year of provisioning to be part of an integrated system of ECD programmes that could include a variety of strategies and a wide range of services, directed at helping families and communities to meet the needs of children from birth to at least nine years old. The introductory section of the IPECD set out in detail the principles of an integrated approach and identified the paramount task as building "a just and equitable system" directed at the "integrated needs of children, women, and families" (DoE,1996, p.12). The policy specifically stated that funding for the Reception Year should not weaken funding for other kinds of services.

Despite the ANC commitment to providing opportunities for wide consultation even after it was elected to power, this did not happen except in Gauteng province. In Gauteng we used action research to engage families and communities in conversation and action to support the well-being of young children, through the Impilo Project. With the support of Education MEC, Mary Metcalfe, the Gauteng Department of Education (GDE) attempted to resist the dominant discourse and included consultation with communities in the research design of the provincial implementation of the national ECD pilot.

The scope of this article only allows for a brief overview of the Impilo Project. I took up the position in GDE as Chief Education Specialist responsible for Primary and ECD policy during the period we were drafting the IPECD. In my new position in GDE, and with the support of Mary Metcalf, we implemented the Impilo Project. I firmly believed at that time that it would be possible through action research to actively mobilize and demonstrate that there were possibilities, other than the single narrative of extending primary school downward. We had to negotiate with the National Department of Education (NDoE) to implement the national ECD pilot flexibly, as the national research design was limited to investigating the costing of one year of provision for four-year old children.

The primary assumption of Impilo was that the well-being of young children depends on the wellbeing of the families and communities. Little can be achieved by taking children out of their homes for a few hours without taking steps to change their socio-economic circumstances. Impilo sought to engage civil society and service providers in conversations about well-being by trying new paradigms, such as shifting from expert solutions to local solutions, and enabling dialogue, rather than merely pouring down simplistic messages for consumption by service users viewed as deficient (Shiva, 2002). Impilo included three linked action research projects for children from birth to nine years. The two additional projects were 
Revealing colonial power relations in early childhood policy...

added as funds became available, but the main project was the provincial implementation of the national ECD pilot, referred to as the district pilot.

\section{Collective Learning through Action}

We contracted different consortia of RTOs, to each work in one of the new education districts in close collaboration with the newly appointed ECD district officials. The aim was to learn with community groups through supporting them to make decisions, and if necessary, we could all learn through small missteps. At the provincial level, I started to meet with my counterparts in other departments such as Health and Welfare, to understand each other's functions and find ways to collaborate. We spent a long time building a shared understanding of the definition of the new umbrella term ' $E C D^{\prime}$ ', as our health comrades pointed out that services and support should start from conception rather than birth. We were able to start building referral systems and help families to access available services across different departments. We also supported organizing and mobilizing to ensure everyone could access the services to which they were entitled and start advocating for additional services to fill the gaps. For example, we talked about food sovereignty and initiated community gardens, rather than merely providing information to families about how they should feed their children and offering some food to a limited number of children who could afford to attend centres. Together, we learned about the importance of building 'networks of care', known as uMusa (acts of kindness), with trusted helpers identified by the communities in which they live.

\section{Deleting Data That Does Not Fit the Frame}

The Director responsible for ECD in NDoE dismissed the idea of allowing community groups, in dialogue with training providers, to make decisions about the kinds of service they wanted and how best to spend their small stipend. She said it could not be accepted as it could lead to corruption. I find this particularly ironic in the light of the scale of corruption committed by ex-President Jacob Zuma ${ }^{16}$. By the time the Impilo Project featured as the lead story in the UNICEF 2000 State of the Word Report (UNICEF, 1999), it was clear that other than the experiences that participants might carry forward, our attempt to take a new narrative into early childhood policy-making had failed.

When I resigned from my position at GDE, I understood what Tsing, 2015, alludes to when she states that "a scalable research project admits only data that already fits the research frame" (Tsing, 2015, p. 38). Before the national ECD pilot started, the decision was made to scale up the one year of provision. Consequently, the national ECD pilot research was designed for scalability and could not accommodate the meaningful diversity sought through Impilo. With no open-ended research questions, the national research could not include any of the Gauteng data. The research design was too narrow to accommodate any complexity and diversity. So it counted the 1000 sites (there were less than 1000 sites in all the other 9 provinces combined), included a short description of Impilo (probably submitted by GDE), noted that Gauteng did not follow the ECD Pilot Project formula of R2 per child per day, and that was that (DoE, 2001b). I also began to realize that in the post-Apartheid national and provincial education departments, 'uncertainty' was the enemy and that power relations subjugated debate about policy options.

Despite the 1992 ANC promise of broad consultation, policy decisions for public provisioning for young children in South Africa during the first two decades of ANC rule have favoured simple solutions that prioritize discrete and fragmented interventions instead of engaging with more complex challenges. The centre-based approach, which was uncritically borrowed from affluent countries with high employment rates and strong welfare programmes, persists as the most familiar and popular kind of ECD service provision. The primary focus of government ECD provisioning since 1996 has been the introduction and gradual extension of one year of additional schooling in the year before children join the formal school system, initially referred to as the Reception Year and now as 'Grade R'. This form of provisioning that

\footnotetext{
${ }^{16}$ On 16 March 2018, it was confirmed by the director of public prosecutions that Zuma (who was President from 2009 to 2018) would face 18 charges of corruption, including more than 700 counts of fraud and money laundering.
} 
reproduces inequality has persisted despite government commitment to consultation and recognition, in new policies, of the need for broader 'integrated' approaches. The next part of my story briefly traces this trajectory and argues that the government commitment to 'evidence-based planning and monitoring' has reinforced this inequitable form of ECD provisioning.

\section{Grade R: Reproducing Inequality on Economic Lines}

In 1996, the ANC government committed to ten years of free and compulsory education, starting with a Reception Year for 5-year-olds (DoE 1996). By the time the Education White Paper 5 on ECD was published in 2001, the national 3-year ECD (Reception Year) pilot had been completed. The ANC's ECD policy priority, as expressed in 2001, was the establishment of a national system of provision for children aged 5 years, with the majority of these classes located within the formal school system and a small number in community-based services (DoE, 2001a, p. 5).

Despite the National Integrated Plan (NIP) (RSA, 2005), the 2005 Children's Act (DSD, 2005) and the National Integrated Early Childhood Development Policy (NIECDP) (Republic of South Africa [RSA], 2015), for nearly 20 years the primary focus of government services for young children has remained the introduction and expansion of this single year of provisioning for children before they enter primary school. Despite the 2010 target for universal access, Grade R is not yet available to all children and those living in urban areas and those with greater financial resources are more likely to be in a Grade $\mathrm{R}$ class (Biersteker, 2018). There is a problem of under-aged children from more resourceful families entering Grade R classes in schools and spending more than one year in that class. These are families who realize they can get cheaper better-quality childcare by manipulating the system. Since those classes attached to schools are better funded, practitioners prefer to be employed in schools. Before the introduction of Grade $\mathrm{R}$, the standard model of ECD provisioning was in community-based centres with children from 3 to 6 years. This set-up more closely aligned to traditional childcare arrangements, that nurtured peer teaching and learning, with children in the village forming friendship groups (Rudolph, 2017). The communitybased system of provision has been eroded by age-segregation and flight of practitioners to better paying jobs in schools.

Drawing on recent research, Biersteker concludes that "while Grade R was established as a means of reducing inequalities, it simply extended the advantage to children in more affluent schools" (Biersteker, 2018, p. 305). After concluding that Grade $\mathrm{R}$ is not cost-effective in terms of learning outcomes, the 2014 evaluation report nevertheless recommends that "the Grade R programme be continued and that ways to improve its impact be explored" (van der Berg et al., 2013, p. 3). The National Department of Basic Education (DBE) agreed with the evaluators and rather than considering a different approach, it committed to improving training, increasing access to materials, developing high quality school readiness tests, and reverting to a higher percentage of community-based classes (DBE, DSD, \& DoH, 2017; Samuels et al., 2015). The government cost-saving strategy to increase the percentage of community sites, after having decimated community-based services through neglect over 20 years, is particularly pernicious. None of these strategies addresses the uneven expenditure across different socio-economic groups, based on the socio-economic inequalities in the entire education system. Although universal provision of Grade R has not been achieved as planned, in 2019 an additional year referred to as grade RR will be introduced, in part to address the problem of under-age children in Grade R (Biersteker, 2018) ${ }^{17}$. Referring to Taylor (2014), Biersteker (2018) explains the expectation that this extra year, with stricter enforcement of age-of-entry, will ensure smooth progress from one grade to another with children of their own age (Biersteker, 2018). This is an example of what Stevens (2011) refers to as the silencing of inequality.

\section{Outcomes-based Planning, Monitoring and Evaluation Deepens Inequality}

The Grade R policy decision, initially drawn from the Apartheid era and sold by Padayachie, has been reinforced through the decision that all South African government planning, monitoring and 
Revealing colonial power relations in early childhood policy...

evaluation functions be centralized in a single high-level Department of Planning, Monitoring and Evaluation (DPME) (The Presidency RSA, 2015). In the context of the 2030 Vision and ANC election manifesto, the 2010 adoption of an outcomes-based approach to public management and the 2011 National Evaluation Policy Framework (NEPF) emphasizes "increasing the utilization of evaluative evidence in planning, budgeting and management decisions" (Amisi, 2015, p. 1). Despite the laudable intention of improving value from government spending, the nature and role of monitoring and evaluation (M\&E), and the way that 'evidence' is understood, will determine whose judgments are valued and what kind of change is possible. The dominant 'scientific evidence' discourses prioritize the perspectives of experts over beneficiaries (Rudolph, Millei, \& Alasuutari, 2019). Communication, in the form of messages, is viewed as a strategy for enlisting civil society buy-in, rather than enabling meaningful conversation that includes all concerned about child and community wellbeing.

A series of articles ${ }^{18}$ published in the African Journal of Education, disseminate monitoring and evaluation developments in South African policy and planning and promote 'evidence' as the key policy driver (Amisi, 2015; Davids et al., 2015; Samuels et al., 2015). Amisi argues for communication as a tool for evaluators to improve the "usability and utility of evaluation evidence" (Amisi, 2015, p. 6). This is what Stevens (2011) refers to as using 'evidence' to sell a chosen story. According to Amisi, the focus on communication among evaluators, practitioners and policymakers as users of evidence, encourages dialogue as adding "meaning to often complex and technical evaluation findings in a way that is understandable and enlightening to the target audience" (Amisi, 2015, p. 5). This confirms that, from the perspective of the Presidency, policy makers assume that avoiding complexity is necessary to sell their policies. There is no reference in any of the articles to dialogue generating new knowledge or the role of service users in the evaluation process. Service users are constructed as deficient, unable to understand or engage constructively with different ideas. Consequently, they need simple messages.

Amisi identifies two separate communication processes, between practitioners and evaluators in the evaluation process, and between government and civil society in different forums, in order to target messages distilled from findings. Amisi cautions that at a later stage when "evaluations become imprinted in the operating processes of government", there will be more scope for evaluation findings to be "communicated transparently and widely", but in the meantime proposes "communication that generates interest and appreciation of evaluations, and encourages the application of lessons learned in policy and management practices" (Amisi, 2015, p. 7). Concerns are raised in all three articles about publishing evaluation findings that could "provide an opportunity to sensationalise critical findings to show government in a bad light" (Davids et al., 2015, p. 7), especially if the DPME independently communicates "evaluation outcomes of another department's programme" (Amisi, 2015, p. 5). This statement highlights government concern for the way it is viewed, rather than the social justice outcomes of their policy choices. Consequently, the singular solution is reinforced by refusing to learn through experience and possible missteps.

\section{A Story without Ending ...}

Early childhood policy-making and evaluation has used 'evidence' selectively in South Africa to avoid complexity, uncertainty, or challenge to the dominant narratives, and in so doing ensures that government decisions are viewed positively. In this way, despite the good intention of the ANC government, inequality has been silenced and even exacerbated through early childhood policy. This kind of mistrust of citizens has been carried into the coercive and heavy-handed government strategy during COVID-19. Government is not linking the disease response to local practical knowledges and culture ${ }^{19}$. Citizens have not been invited to collaborate in solving the huge problems facing the country. Dicta are handed down in the form of simplistic messaging, without any explanation of the thinking behind these

\footnotetext{
18 The first two articles relate directly to ECD and the third to the overarching national monitoring and evaluation process.

${ }^{19}$ Important lessons learnt in the Ebola crisis in West Africa and the AIDS pandemic in South Africa. https://steps-centre.org/blog/science-uncertainty-and-the-covid-19response/
} 
decisions. Most school children rely on the one meal a day they receive through the School Nutrition Program. Many early childhood workers rely on the meagre fees paid to attend large ECD centres. Consequently, experts debate whether schools and early childhood services should open, rather than engaging civil society in finding creative ways to feed and take care of children in their communities.

The kind of integrated policy-making process used in Impilo, based on trusting citizens and enabling co-operation between government and civil society, could provide the kind of environment that is urgently needed, so that citizens can understand as much as possible and choose to co-operate with government. Impilo recognized the potential of a strong network of trusted helpers in every community, who know where young children are and engage with families as partners. They could surely play an important role in helping families access food and care close to their homes. As 'essential workers' with the necessary protective equipment they could link with families and find out the nature and location of urgent needs, including food, water, protection, exercise and sunlight, or anything else our government departments might not yet have identified. They could engage in dialogue to help everyone to understand the complexity of the pandemic, avoid discrimination and work together to experiment in finding the best strategies for survival and willingly implementing public health measures.

In terms of policy for young children beyond the immediate escalating crisis of the pandemic, and in light of the expressed intention of our President's messages during COVID-19 to address inequality and forge a new economy, it is time to consider other options to the single story that has dominated early childhood policy. I pose the following questions to restart conversations: Can we learn from the uncertainty of COVID-19 in ways that open up debate and encourage a more democratic deliberation? Can government acknowledge missteps and be open to proposals from service users? How can we extend the notion of evidence, and include in our conversations early childhood theorists who have long been calling for the reconceptualization of early childhood policy, such as Peter Moss who promotes hope through contestation (Moss, 2015)? Can we imagine another way of knowing, being and communicating that does not advantage the privileged few with devices, unlimited airtime and data packages? Can we rebuild livelihoods and solidarity through recognizing the agency and voice of communities? Can we all work together towards the vision of a convivial society set out in the 1955 Freedom Charter?

\section{Declarations}

Acknowledgements: The author acknowledges and would like to express her deep appreciation to her doctoral supervisors Professor Zsuzsa Millei and Professor Maarit Alasuutari for their prodigious help, support and encouragement.

Competing interests: The author declares that she has no competing interests

Funding: The author received a scholarship from the University of Jyväskylä during part of the period of work on this article.

\section{References}

Amisi, M. M. (2015). Development of South Africa's national evaluation policy and system 2011-2014. African Evaluation Journal, 3(1), 109. https://doi.org/10.4102/aej.v3i1.109

ANC. (1992a). Ready to Govern: ANC policy guidelines for a democratic South Africa, adopted at the ANC National Conference. Johannesburg, South Africa: Policy Unit of the African National Congress.

ANC. (1992b). Regional policy consultative conference - PWV region 9 -10 May 1992. Retrieved from archive of Mary Metcalf.

ANC. (1994). A policy framework for education and training (draft dicussion document). Johannesburg: ANC Education Department.

Arango, M., \& Nimnicht, G. (1987). Implementing alternative programmes for the development of young children: A challenge for social and economic development. In O. Van den Berg, \& T. Vergnani (Eds.), Door to the future: The prechool child in South Africa: A book of readings (pp. 37 - 56). Belveille, South Africa: University of the Western Cape.

Arango, M., \& Nimnicht, G. (2004). Twenty years on: A report of the PROMESA programme in Colombia. Colombia: The Bernard van Leer Foundation.

Biersteker, L. (1992). Emerging early childhood educare policy in South Africa. Retrieved from archive of Linda Biersteker. 
Revealing colonial power relations in early childhood policy...

Biersteker, L. (2018). Early childhood education and social transformation in South Africa: The emergence of early childhood education as a priority in South Africa. In J. L. Roopnarine, J. E. Johnson, S. F. Quinn, \& M. M. Patte (Eds.), Handbook of international perspectives on early childhood education (pp. 296-310). New York: Routledge.

Chawla, D., \& Atay, A. (2018). Introduction: decolonizing autoethnography. Cultural studies $\leftrightarrow$ Critical methodologies, 18(1), 3-8. https://doi.org/10.1177/1532708617728955

Christie, P. (2006). Changing regimes: Governmentality and education policy in post-apartheid South Africa. International Journal of Educational Development, 26(4), 373-381. https://doi.org/10.1016/j.ijedudev.2005.09.006

Davids, M., Samuels, M.-L., September, R., Moeng, T. L., Richter, L., Mabogoane, ... Buthelezi, T. (2015). The pilot evaluation for the National Evaluation System in South Africa - A diagnostic review of early childhood development. African Evaluation Journal, 3(1), 1-7. https://doi.org/10.4102/aej.v3i1.141

DBE, DSD, \& DoH. (2017). Portfolio committee briefing on Early Childhood Development. Retrieved from https://slideplayer.com/slide/12195554/

DoE. (1996). Interim policy for early childhood development. Retrieved from https://www.gov.za/documents/early-childhooddevelopment-interim-policy-0

DoE. (2001a). Education White Paper No 5, Early Childhood Education: Meeting the challenge of Early Childhood Development. Pretoria Retrieved from https://sparrowportal.co.za/wp-content/uploads/2016/04/White-Paper-5.pdf

DoE. (2001b). Report on the National ECD Pilot Project. Pretoria: Department of Education Retrieved from http://www.westerncape.gov.za/text/2003/national report ecd pilot 2001.pdf

DSD. (2005). The Children's Act 38. Pretoria: Government Printers.

Escobar, A. (Ed.) (2020). Pluriversal politics : The real and the possible. Durham and London: Duke University Press. https://doi.org/10.1515/9781478012108

Fielding, M., \& Moss, P. (2010). Radical education and the common school : A democratic alternative. London: Routledge. https://doi.org/10.4324/9780203837405

Foucault, M. (2000). Ethics : subjectivity and truth (P. Rabinow, Trans.). London : Penguin.

Freire, P. (1970). Pedagogy of the Oppressed. New York: The Continuum International Publishing Group Ltd.

Green, L. J. (2012). Beyond South Africa's' indigenous knowledge-science'wars. South African Journal of Science, 108(7-8), 44-54. http://dx.doi.org/10.4102/sajs.v108i7/8.631

Hope, A., \& Timmel , S. (1984). Training for transformation. A handbook for community workers. Gweru: Mambo Press.

Illich, I. D. (1973). Inverting Politics, Retooling Society: From Tools for Conviviality. The American Poetry Review, 2(3), 51-53. Retrieved from http://www.jstor.org/stable/2777463

Mignolo, W. D. (2007). Introduction: Coloniality of power and de-colonial thinking. Cultural Studies, 21(2-3), 155-167. https://doi.org/10.1080/09502380601162498

Moss, P. (2007). Bringing politics into the nursery: Early childhood education as a democratic practice. European Early Childhood Education Research Journal, 15(1), 5-20. https://doi.org/10.1080/13502930601046620

Moss, P., \& Dahlberg, G. (2008). Beyond Quality in Early Childhood Education and Care - Languages of Evaluation. New Zealand Journal of Teachers' Work, 5(1), 3-12. Retrieved from http://urn.kb.se/resolve?urn=urn:nbn:se:su:diva-74820

Moss, P. (2014). Transformative change and real utopias in early childhood education. Hoboken: Taylor and Francis.

Moss, P. (2015). There are alternatives! Contestation and hope in early childhood education. Global Studies of Childhood, 5(6), 226-238. https://doi.org/10.1177/2043610615597130

Moss, P. (2019). Alternative Narratives in early childhood, or why contest early childhood? London: Routledge https://doi.org/10.4324/9781315265247

Padayachie, R. (1993a). ANC policy discussion document (draft 1): Early Childhood Educare Retrieved from archive of Linda Biersteker.

Padayachie, R. (1993b). Invitation African National Congress: Early Childhood Educare policy workshop. Retrieved from archive of Linda Biersteker.

Padayachie, R. (1993c). Presentation to the ANC Education Consultative Workshop. Retrieved from archive of Linda Biersteker.

Padayachie, R., Atmore, E., Biersteker, L., King, R., Matube, J., Muthayan, S., \& Evans, J. (1994). Report of the South African Study on Early Childhood Development: Recommendations for Action in Support of Young Children. Johannesburg / Washington DC: Centre for Education Policy Development / World Bank.

Pillow, W. (2003). Confession, catharsis, or cure? Rethinking the uses of reflexivity as methodological power in qualitative research. International Journal of Qualitative Studies in Education, 16(2), 175-196. https://doi.org/10.1080/0951839032000060635 


\section{Norma RUDOLPH}

RSA. (2005). National Integrated Plan for Early Childhood Development in South Africa (NIP) 2005-2010. Pretoria: Government printers

RSA. (2015). National Integrated Early Childhood Development Policy. Pretoria: Government Printers

Rudolph, N. (1993). The nurture of human nurture: Constructivist stepping stones guide the Woz' obona educare curriculum. Special project for BED EDUC 487. Department of Education. University of Witwatersrand.

Rudolph, N. (2017). Hierarchies of knowledge, incommensurabilities and silences in South African ECD policy: Whose knowledge counts? Journal of Pedagogy, 8(1), 77-98. https://doi.org/10.1515/jped-2017-0004

Rudolph, N., Millei, Z., \& Alasuutari, M. (2019). Data practices and inequality in South African early childhood development policy: Technocratic management versus social transformation. South African Journal of Childhood Education, 9(1), a756. https://doi.org/10.4102/sajce.v9i1.756

Samuels, M., Taylor, S., Shepherd, D., van der Berg, S., Jacob, C., Deliwe, C., \& Mabogoane, T. (2015). Reflecting on an impact evaluation of the Grade R programme: Method, results and policy responses. African Evaluation Journal, 3(1), a139. https://doi.org/10.4102/aej.v3i1.139

September, R., \& Mokgoro, Y. (1993). An Agenda for Action: The Launch of the Situation Analysis Report. National Children's Rights Committee, Johannesburg (1: 86808: 205: 9).

Shiva, V. (2002, September/October). Paradigm shift: Rebuilding true security in an age of insecurity. Resurgence, September/October 2002(214), 30-32.

Stevens, A. (2011). Telling policy stories: An ethnographic study of the use of evidence in policy-making in the UK. Journal of Social Policy, 40(2), 237-255. https://doi.org/10.1017/S0047279410000723

Taylor, N. (1992). The National Education Policy Investigation: Early Childhood Educare. Cape Town, Oxford University Press/NECC.

The Presidency RSA (2015). Strategic Plan of the Department of Planning, Monitoring and Evaluation 2015-2020. Retrieved from https://www.dpme.gov.za/publications/Strategic\%20Plan\%20and\%20Annual\%20Reports/DPME\%20Strategic\%20Plan\%202 015-2020.pdf

Tsing, A. L. (2015). The mushroom at the end of the world: On the possibility of life in capitalist ruins. Princeton: Princeton University Press.

UNICEF. (1999, 9 December). South Africa: Helping children by helping families (Impilo). The State of the World's Children 2000.

Van den Berg, O., \& Vergnani, T. (1986). Providing services for preschool children in South Africa. Report of an investigation conducted on behalf of the Southern African Association for Early Childhood Education: University of the Western Cape.

van der Berg, S., Girdwood, E., Shepherd, D., Van Wyk, C., Kruger, J., Viljoen, J., ... \& Ntaka, P. (2013). The impact of the introduction of grade $R$ on learning outcomes. University of Stellenbosch, Stellenbosch. Retrieved from http://resep.sun.ac.za/wpcontent/uploads/2014/06/Grade-R-Evaluation-1-3-25-Final-Unpublished-Report-13-06-17.pdf

Williams, T., \& Samuels, M. (2001). The Nationwide Audit of ECD Provisioning in South Africa. Pretoria, South Africa: The Department of Education. 